Portland State University

PDXScholar

\title{
Fire Modulates Climate Change Response of Simulated Aspen Distribution Across Topoclimatic Gradients in a Semi-Arid Montane Landscape
}

\author{
Jian Yang \\ University of Nevada, Reno \\ Peter J. Weisberg \\ University of Nevada, Reno \\ Douglas J. Shinneman \\ U.S. Geological Survey \\ Thomas E. Dilts \\ University of Nevada, Reno \\ Susan L. Earnst \\ U.S. Geological Survey
}

Follow this and additional works at: https://pdxscholar.library.pdx.edu/esm_fac

PPraxtopabe Eorvadditionablagthenses Commons, Forest Management Commons, and the Plant Sciences Commons

Let us know how access to this document benefits you.

\author{
Citation Details \\ Yang, J., Weisberg, P. J., Shinneman, D. J., Dilts, T. E., Earnst, S. L., \& Scheller, R. M. Fire modulates climate \\ change response of simulated aspen distribution across topoclimatic gradients in a semi-arid montane \\ landscape. Landscape Ecology, 1-19.
}

This Article is brought to you for free and open access. It has been accepted for inclusion in Environmental Science and Management Faculty Publications and Presentations by an authorized administrator of PDXScholar. Please contact us if we can make this document more accessible: pdxscholar@pdx.edu. 
Authors

Jian Yang, Peter J. Weisberg, Douglas J. Shinneman, Thomas E. Dilts, Susan L. Earnst, and Robert M. Scheller

This article is available at PDXScholar: https://pdxscholar.library.pdx.edu/esm_fac/117 


\title{
Fire modulates climate change response of simulated aspen distribution across topoclimatic gradients in a semi-arid montane landscape
}

\author{
Jian Yang • Peter J. Weisberg • \\ Douglas J. Shinneman - Thomas E. Dilts • \\ Susan L. Earnst $\cdot$ Robert M. Scheller
}

Received: 26 June 2014 / Accepted: 16 January 2015

(C) Springer Science+Business Media Dordrecht 2015

\begin{abstract}
Content Changing aspen distribution in response to climate change and fire is a major focus of biodiversity conservation, yet little is known about the potential response of aspen to these two driving forces along topoclimatic gradients.
\end{abstract}

Electronic supplementary material The online version of this article (doi:10.1007/s10980-015-0160-1) contains supplementary material, which is available to authorized users.

J. Yang · P. J. Weisberg · T. E. Dilts

Department of Natural Resources and Environmental

Science, University of Nevada-Reno, 1664 N. Virginia

Street, M.S. 186, Reno, NV 89557, USA

J. Yang $(\bowtie)$

State Key Laboratory of Forest and Soil Ecology, Institute of Applied Ecology, Chinese Academy of Sciences,

Shenyang 110016, China

e-mail: jian.yang@uky.edu

Present Address:

J. Yang

Department of Forestry, TP Cooper Building, University

of Kentucky, Lexington, KY 40546, USA

D. J. Shinneman · S. L. Earnst

U.S. Geological Survey, Forest and Rangeland Ecosystem

Science Center, Boise, ID 83706, USA

R. M. Scheller

Environmental Science and Management Department, Portland State University, PO Box 751, Portland,

OR 97207, USA
Objective This study is set to evaluate how aspen distribution might shift in response to different climate-fire scenarios in a semi-arid montane landscape, and quantify the influence of fire regime along topoclimatic gradients.

Methods We used a novel integration of a forest landscape succession and disturbance model (LAN DIS-II) with a fine-scale climatic water deficit approach to simulate dynamics of aspen and associated conifer and shrub species over the next 150 years under various climate-fire scenarios.

Results Simulations suggest that many aspen stands could persist without fire for centuries under current climate conditions. However, a simulated $2-5{ }^{\circ} \mathrm{C}$ increase in temperature caused a substantial reduction of aspen coverage at lower elevations and a modest increase at upper elevations, leading to an overall reduction of aspen range at the landscape level. Increasing fire activity may favor aspen increase at its upper elevation limits adjacent to coniferous forest, but may also favor reduction of aspen at lower elevation limits adjacent to xeric shrubland.

Conclusions Our study highlights the importance of incorporating fine-scale terrain effects on climatic water deficit and ecohydrology when modeling species distribution response to climate change. This modeling study suggests that climate mitigation and adaptation strategies that use fire would benefit from consideration of spatial context at landscape scales. 
Keywords Quaking aspen · Fire disturbance . Gradient analysis · Great Basin · LANDIS-II · Climatic water deficit

\section{Introduction}

Vegetation distribution in montane environments is sensitive to climate change, yet the nature of plant response along topoclimatic gradients is not always straightforward (Hughes 2000; Chen et al. 2011). The responses of individual plant species to climate change vary greatly, and may include moving to higher (Beckage et al. 2008; Lenoir et al. 2008) or lower elevations (Crimmins et al. 2011), becoming denser (Linares et al. 2009), or experiencing extensive mortality (Breshears et al. 2005; Allen et al. 2010). The effect of climate change on vegetation distribution is contingent upon dynamic interactions among species traits, environmental setting, and disturbance (Lenoir et al. 2010). Specifically, plant response is influenced by growing conditions (e.g., soil-water availability) and further determined by population-level processes, including growth, mortality, and recruitment, as well as community-level and landscape-level processes, such as competition, dispersal, and disturbance (Araújo and Luoto 2007; Breshears et al. 2008; Lenoir et al. 2010).

Fire is an important natural disturbance in many terrestrial ecosystems, helping to shape the distribution of plant communities at landscape- to global-scales (Bond and Keeley 2005) and contributing to the evolution of plant traits (Keeley et al. 2011). In montane landscapes, distinct vegetation communities occur along elevation gradients and are typically associated with unique natural fire regimes. However, key fire regime characteristics (e.g., mean fire return interval, size and severity distributions) can vary greatly among and even within ecosystem types (Schoennagel et al. 2004; Baker 2009). Moreover, humans influence natural fire regimes through a variety of mechanisms (e.g., fire suppression, livestock grazing), and anthropogenic climate change will likely further alter fire regimes and vegetation response (Lenihan et al. 2008; Flannigan et al. 2009; Krawchuk et al. 2009).

Understanding how future fire regimes and climate change will affect vegetation distribution is critical for developing climate mitigation and adaptation strategies. For instance, both the use and suppression of fire could provide important tools to constrain undesirable climate change effects at landscape scales (Littell et al. 2012). Altered fire regimes may play a critical role in accelerating climate-induced changes in vegetation, and the importance of integrating disturbance regime and climate change into projections of climate change response has long been recognized (Loehle and LeBlanc 1996). Although climate change studies have projected vegetation redistribution along environmental and bioclimatic gradients (e.g., Rehfeldt et al. 2006; Kelly and Goulden 2008; Crimmins et al. 2011), relatively few studies have examined how fire might influence plant response to future climate change across these gradients (e.g., Lenihan et al. 2008; Littell et al. 2010; Westerling et al. 2011).

Quaking aspen (Populus tremuloides) forms one of the few deciduous forest communities in the generally semi-arid, mountainous landscapes of interior western North America (hereafter, "Mountain West"), where it is economically important (McCool 2001) and disproportionately supports diverse floras and faunas relative to its areal extent (Chong et al. 2001). In recent decades, widespread aspen decline and sudden aspen mortality events across the Mountain West have been attributed to fire suppression, conifer competition, increasing water stress and drought, insect outbreaks, and excessive browsing by wildlife and livestock (Kay 1997; Hessl and Graumlich 2002; Worrall et al. 2010; Hanna and Kulakowski 2012). Altered fire regimes and climate change are likely to be critical determinants of future distributions of aspen across the Mountain West (Kashian et al. 2007; Rehfeldt et al. 2009; Anderegg et al. 2013). Although some aspen stands in the Mountain West are considered stable and can persist for multiple generations even in the absence of fire, other aspen communities are firedependent and seral to conifers when fire is absent (Shinneman et al. 2013). Thus, fire influences the extent and persistence of aspen on many Mountain West landscapes (Romme et al. 2005; Kulakowski et al. 2006). Adequate soil- and atmospheric-moisture are also key determinants of aspen distribution in the generally semi-arid Mountain West, and climate change is likely to result in temporally and spatially shifting patterns of water deficits and drought events that lead to aspen mortality over time (Worrall et al. 2010; Anderegg et al. 2013; Hanna and Kulakowski 2012). Given the economic and ecological importance of aspen, there is an urgent need to improve our 
understanding of how this foundation tree species and associated natural communities may respond to alternative future fire and climate scenarios. Moreover, understanding the potential for fire and climate change to collectively influence a wide-ranging species such as aspen may provide insight into broader vegetation dynamics under climate change.

Spatially-explicit vegetation models can provide insights into likely future distributions in a climate change context. Ecological niche-based models use empirical relationships between environmental variables and observed patterns of species occurrence to project species distribution in response to climate change (e.g., Rehfeldt et al. 2006; Iverson and McKenzie 2013), but generally omit key biological and disturbance processes that strongly affect species' realized niches (Morin and Thuiller 2009). In contrast, species-specific, process-based forest landscape models (FLMs) are capable of simulating vegetation dynamics on landscapes by explicitly considering migration constraints (seed dispersal), demographic processes (growth, mortality, and establishment), biological competition, and disturbance (Scheller and Mladenoff 2005). FLMs have been widely applied in boreal (Gustafson et al. 2010; Shinneman et al. 2012), alpine (Schumacher and Bugmann 2006; Temperli et al. 2013), temperate (Scheller and Mladenoff 2005), and seasonally arid Mediterranean forests (Syphard et al. 2011; Karam et al. 2013) to address succession-disturbance interaction and forest management research questions. However, FLMs are less commonly used in semi-arid mountain regions, where forest patches are intermixed within a shrubland matrix (e.g., sagebrush steppe). This is partly because most FLMs cannot adequately account for the role of fine-scale climatic water deficit (CWD) (Schlaepfer et al. 2012) in determining climate and edaphic effects on species recruitment probability—a key model input parameter in FLMs to simulate species distribution response to climate (Xu et al. 2009).

We used a dynamic forest landscape model (LAN DIS-II) coupled with a fine-scale CWD approach (Lutz et al. 2010) to project the potential effects of climate change on vegetation distribution and abundance in a mostly semi-arid mountainous landscape in the Great Basin of western North America. We explored the potential for interactions between climate change and fire regime to influence the future distribution of aspen and associated conifer and shrub species using a factorial design that reflects three levels of climate change (under current, low-, and high- carbon emissions scenarios) and three fire regime scenarios (contemporary fire regime, fire exclusion, and frequent fire regime scenarios). The primary objectives of this study were to: (1) develop reasonable estimates of recruitment for major forest species and functional shrubland-grass vegetation types, across topographic and climatic ("topoclimatic") gradients, under alternative future climate scenarios; (2) incorporate these recruitment estimates ('establishment probabilities') within a FLM to project landscape-level vegetation composition dynamics under alternative climate and fire regime scenarios; (3) evaluate how aspen distribution varies across topoclimatic gradients in response to different climate-fire scenarios, and identify potential landscape settings that might serve as aspen-refugia under less-suitable future climates; and (4) quantify the influence of fire regime on climatic response of aspen distribution along topoclimatic gradients.

\section{Materials and methods}

Study area

Our 344,380-ha study area includes the Jarbidge and Mountain City Ranger Districts of the HumboldtToiyabe National Forest in northeastern Nevada, USA $\left(41.30^{\circ}\right.$ to $42.00^{\circ} \mathrm{N}$ and $115.00^{\circ}$ to $116.17^{\circ} \mathrm{W}$; Fig. 1$)$. Topography is defined by the Jarbidge, Bull Run, and Independence Mountains, with elevations ranging from 1,490 to $3,270 \mathrm{~m}$. January mean temperatures averaged from 1971 to 2000 were $-2.9^{\circ} \mathrm{C}$ at elevations below $1,900 \mathrm{~m}$ and $-7.51{ }^{\circ} \mathrm{C}$ above $3,000 \mathrm{~m}$. July mean temperatures were 18.55 and $12.05{ }^{\circ} \mathrm{C}$ at those two elevation bands, respectively. The climate is semi- or seasonally-arid, with annual precipitation ranging from $383 \mathrm{~mm}$ at lower elevations to $1,061 \mathrm{~mm}$ at higher elevations and mostly occurring during winter and spring (based on PRISM data, Daly et al. 2008). Natural vegetation consists of a matrix of big sagebrush (Artemisia tridentata Nutt.) at lower elevations, that is increasingly interspersed with herbaceous meadows, riparian vegetation, small patches of mesic mountain shrubs including mountain snowberry (Symphoricarpos oreophilus), serviceberry (Amelanchier spp.), and shiny-leaf ceanothus 
Fig. 1 Location of the study area within the state of Nevada, USA, and its vegetation distribution and burned patches reported by Monitoring Trends in Burn Severity (MTBS) project (www.mtbs.gov) from 1984 to 2007

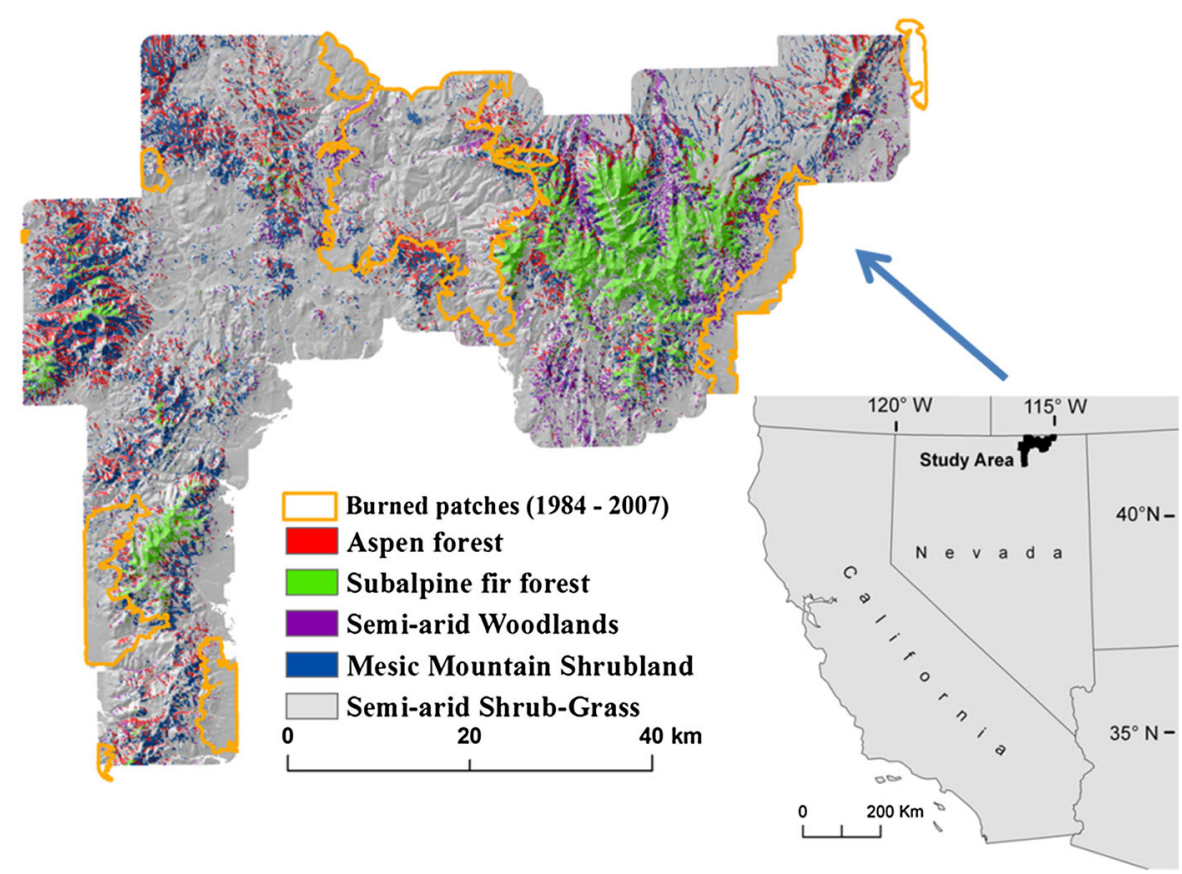

(Ceanothus velutinus), and forest communities at higher elevations (Beck et al. 2006; USFS Humboldt-Toiyabe National Forest Existing Vegetation Map). Forest composition varies with elevation, as follows: (1) higher elevations $(>2,400 \mathrm{~m})$ are dominated by subalpine fir (Abies lasiocarpa), with scattered populations of limber pine (Pinus flexilis), whitebark pine (Pinus albicaulis), and quaking aspen (P. tremuloides Michx.); (2) middle elevations generally contain pure aspen or curl-leaf mountain mahogany (Cercocarpus ledifolius) woodlands scattered among big sagebrush communities; and (3) lower elevations $(<2,100 \mathrm{~m})$ are generally treeless, with the exception of occasional riparian forests and scattered Utah juniper (Juniperus osteosperma) woodlands.

Wildfire is an important natural disturbance in the Interior West. Studies have shown that historical fire frequency for mid-elevation dry forests is often higher than at either lower or higher elevations due to a balance between the production and desiccation of fine fuels (Heyerdahl et al. 2001; Schoennagel et al. 2004). However, according to MTBS (Monitoring Trends in Burn Severity) data (http://www.mtbs.gov), of the $18 \%$ of the study area landscape that burned during a 24-year contemporary period (1984-2007), the majority was at low elevations (Fig. 1). Specifically, approximately $40 \%$ of area in sagebrush shrubland at elevations $<2,100 \mathrm{~m}$ was burned during the study period. In contrast, only $4 \%$ of the area burned occurred at high elevations $(2,400-2,500 \mathrm{~m})$ where subalpine forests dominate. The extremely low burned area proportion reported by the MTBS data for high elevations was partly due to the inadequacy of the short 24-year sample period for capturing the large but infrequent fires that are characteristic of subalpine fir forests. The high relative percentage of burned area for low elevations was partly due to the invasion of cheatgrass (Bromus tectorum), an annual grass that promotes and benefits from frequent fires (Mack and D'Antonio 1998; Chambers et al. 2007). Historically, aspen in the study area were likely both fire-independent and fire-dependent. Stable aspen communities persist even in the absence of fire, especially on portions of the landscape where conifer competitors are rare or absent. Seral aspen communities are more common where subalpine fir dominates and, on these portions of the landscape, aspen may be replaced by the more shade-tolerant fir when fire is absent over long time periods (Shinneman et al. 2013, Shinneman et al. unpublished data).

\section{Description of LANDIS-II model}

We used LANDIS-II (Scheller et al. 2007) to simulate combined effects of climate change and fire disturbance on vegetation dynamics. LANDIS-II is a FLM 
derived from the LANDIS model (Mladenoff and He 1999) that is more flexible with modern software engineering techniques and more mechanistic with the incorporation of additional key state variables (e.g., biomass) and ecological processes (e.g., inter-species competition for "growing space" and senescence). It consists of a core collection of libraries and optional extensions that represent ecological processes such as seed dispersal, succession, and fire. Within LANDISII, the landscape is represented by a grid of interacting cells. Each cell may contain multiple tree or shrub species, and each species can have one or many age cohorts. Unlike early LANDIS models, which only tracked the presence and absence of each age cohort, the Biomass Succession extension of LANDIS-II also tracks the aboveground biomass of each age cohort and coarse- and fine-dead biomass pools for each cell. LANDIS-II simulates ecological processes occurring at the cell scale (e.g., competition, seedling establishment, age-related mortality) and at the landscape scale (e.g., seed dispersal and fire disturbance). Simulation output includes maps of forest conditions such as age structure, biomass, disturbance type and severity.

LANDIS-II requires stratification of a heterogeneous landscape into environmentally homogenous land types based on climate, soil or terrain attributes, so that within each land type species establishment probabilities (SEPs) are the same. Simulated vegetation succession is driven by species life history attributes (e.g., shade tolerance), SEPs, cohort growth rate and competitive interactions among cohorts (Scheller and Mladenoff 2004). Cohort biomass net accumulation is calculated as net primary production (NPP) minus development- and age-related mortality. Cohort NPP is based on the maximum growth rate (i.e., maximum aboveground net primary production [maxANPP]) specific to individual species and land type and the available growing space. Developmentrelated cohort biomass mortality is based on previous biomass and the age of a cohort. Development mortality is low when a cohort is young or small, accelerates during the stem-exclusion phase, and plateaus at maturity. Seed dispersal is simulated with a double exponential seed dispersal algorithm to determine the probability of parent tree seeds reaching another cell on the modeled landscape (Ward et al. 2005). The seed dispersal probability curve is defined by two dispersal distance parameters: effective distance and maximum distance. The effective distance defines the farthest distance that $95 \%$ of the seed rain will reach in any direction away from the parent cohort. The maximum distance defines the farthest distance for the remaining $5 \%$ of the seed rain. Once a seed arrival event is simulated, the model will check the site condition based on SEPs so that seedling establishment is more probable in the land types with suitable environmental (e.g., temperature and water availability) settings. For species such as aspen that can resprout after fire, LANDIS-II uses a user-defined vegetative reproductive probability to simulate its root suckering. The recruitment of established seedlings or suckers into a viable cohort is further determined by inter-species competition for the "growing space" and light. This is simulated by comparing the species' shade tolerance with the light available at ground level within a cell, which is computed as a function of aboveground biomass (Scheller and Mladenoff 2004).

We used a modification of the base fire extension (version 3.0) to simulate fire disturbance. The extension stratifies the landscape into multiple fire regime units (FRUs). Each FRU has a unique fire ignition density (number of fire ignitions per $\mathrm{km}^{2}$ per year), fire rotation period (FRP: defined as number of years necessary to burn an area equal to the entire area of FRU), and mean fire size. The modified extension uses a hierarchical fire frequency model to simulate fire occurrence (Yang et al. 2004), in which fire ignition is simulated as a Poisson process and fire spread is simulated as a percolation process (Yang et al. 2008). Fire severity is simulated as a function of time-sincelast-fire (a surrogate of fuel loading), species fire tolerance, and age susceptibility to determine the combination of species cohorts killed and survived (Sturtevant et al. 2009). In the subsequent modeling iteration, LANDIS-II will determine how much "growing space" within a burned site is released and simulates following succession processes with enhanced recruitment probabilities for the early successional species as the competition from established plants is reduced after the fire.

\section{LANDIS-II model parameterization and CWD approach}

Major parameters for LANDIS-II included raster maps (90-m cell size) of initial vegetation species cohorts, land types, and FRUs, species life history attributes, maximum aboveground net primary productivity 
(ANPP), and SEP by species and land type. The initial species age-cohort map was derived from the USFS Humboldt-Toiyabe National Forest Existing Vegetation Map (http://www.fs.usda.gov/main/htnf/landmana gement/gis), forest inventory analysis (FIA) data (http:// www.fia.fs.fed.us/), and field survey tree-ring data (Shinneman et al. unpublished data). For every species in each cell in the USFS vegetation map, we randomly populated age cohort information from age structures derived from the FIA and tree-ring data. The land type map was derived from elevation and annual CWD because both variables were highly correlated with plant distribution in this landscape. CWD in particular has been shown to be superior to using precipitation and temperature for modeling species distributions, as it simultaneously combines the climatic demand for water (potential evapotranspiration) with the supply (precipitation and snowmelt) into a single measure (Stephenson 1998). We used the approach outlined by Lutz et al. (2010) which defines annual CWD as the sum of the difference between monthly potential evapotranspiration and monthly actual evapotranspiration for all months. Potential evapotranspiration was calculated from a 30 year average of PRISM temperature data (Daly et al. 2008) and modified to account for topography by using the heat load index of McCune and Keon (2002) as a multiplier. Water supply inputs were calculated as the sum of precipitation that falls as rain plus the month's snowmelt (Lutz et al. 2010). When potential evapotranspiration exceeded water supply, actual evapotranspiration was calculated as water supply plus a fraction removed from soil storage (Lutz et al. 2010). Due to the lack of detailed spatial soil data available for this region, we used coarse-level STATSGO data to derive the average soil water holding capacity for Great Basin shrubland $(100 \mathrm{~mm})$. We used this average for mid-elevation areas and varied it from $65 \mathrm{~mm}$ along ridgetops to $125 \mathrm{~mm}$ in valley bottoms. CWD was reclassified into five classes (0-40, 40-80, 80-120, 120-160, >160 mm, Appendix S1). We then combined the five CWD classes with 12 elevation bands $(<1900$, 1900-2000, 2100-2200,..., 2800-2900, $\geq 2900 \mathrm{~m}$ ), resulting in a total of 59 active land types (the fifth CWD class was absent at the highest elevation band). Generally, lower elevations had a higher proportion of land types with high (i.e., dry) CWD classes and vice versa (Appendix S2). Riparian areas were excluded in our simulation and treated as an inactive landtype because the eco-hydrological processes influencing riparian vegetation are not well represented in the LANDIS model, and coverages of riparian vegetation $(<3 \%$ of study area) and riparain aspen (2.6\% of the existing aspen stands) were minor. We developed FRUs based on relationships between area burned and elevation (derived from 1984-2007 MTBS data), and further parameterized using information on the fire ecology of sagebrush steppe, aspen, and subalpine fir (e.g., USDA Forest Service Fire Effects Information System; http:// www.fs.fed.us/database/feis). This resulted in a coarsescale, contemporary fire regime map (Appendix S3) with FRUs representing four fire rotation periods $(60$, 120,250 , and 500 years) that increase in length with elevation (Appendix S4).

Species life history attributes (Table 1) were derived from the USDA Forest Service Silvics of North America, the USDA Forest Service Fire Effects Information System, and LANDIS-II literature. Conventional wisdoms regarding aspen regeneration in the intermountain west suggest that unlike its eastern counterpart, reproduction of western aspen is almost exclusively vegetative, except on some marginal sites following high-severity fire disturbance (Kay 1993; Romme et al. 2005). Consequently, many landscape models of western aspen dynamics didn't consider sexual reproduction even though its seeds can be dispersed over great distance (e.g., Strand et al. 2009a). However, recent discoveries suggest that seedling establishment is common enough to be ecologically important for aspen persistence on the landscape (Long and Mock 2012). In light of this changing view on aspen regeneration, we set aspen's effective dispersal distance to $10 \mathrm{~m}$ to simulate the lateral expansion of aspen through cloning, and maximum seed dispersal distance to $1,000 \mathrm{~m}$ to simulate its infrequent recruitment through longdistance dispersal. To account for negative effects of ungulate herbivory on aspen vegetative regeneration, we set aspen's vegetative reproductive probability as 0.9 (also see LANDIS-II literature $\mathrm{Xu}$ et al. 2009; Gustafson et al. 2013). We also included a herbaceous pseudo-species (HERB) in the simulation to model fast colonization of ruderal species in the burned patches, which could exert strong competition effects on the establishment of tree and shrub species. Because LANDIS-II model was originally developed for simulating tree species and changing composition of herbaceous community was not part of our modeling objectives, we used this pseudo-species 
Table 1 Species life history attributes for LANDIS-II modeling

\begin{tabular}{|c|c|c|c|c|c|c|c|}
\hline Species & LONG & MTR & ST & FT & $\mathrm{ED}$ & MD & VP \\
\hline Aspen & 150 & 10 & 2 & 2 & 10 & 1,000 & 0.9 \\
\hline Subalpine fir & 250 & 30 & 4 & 3 & 100 & 200 & 0.0 \\
\hline Limber pine & 500 & 30 & 3 & 4 & 100 & 5,000 & 0.0 \\
\hline Utah juniper & 650 & 30 & 3 & 3 & 100 & 1,000 & 0.0 \\
\hline Mountain mahogany & 500 & 20 & 3 & 3 & 100 & 1,000 & 0.1 \\
\hline Mountain shrubs & 100 & 10 & 2 & 1 & 50 & 500 & 0.3 \\
\hline Sagebrush & 100 & 5 & 1 & 1 & 50 & 500 & 0.0 \\
\hline Herbaceous & 20 & 1 & 1 & 1 & 500 & 5,000 & 0.5 \\
\hline
\end{tabular}

LONG longevity (year), MTR maturity age (year), $S T$ shade tolerance (1 least tolerant and 5 most tolerant), $F T$ fire tolerance (1 least tolerant and 5 most tolerant), $E D$ effective seed dispersal distance (m), $M D$ maximum seed dispersal distance (m), $V P$ vegetative reproductive probability

HERB to represent both the annuals (including cheatgrass) and perennials. HERB was parameterized with a maximum seed dispersal distance of $5,000 \mathrm{~m}$ to represent dispersal capabilities of annual species, and its vegetative reproductive probability was set at 0.5 to reflect the resprouting potential of native perennial bunchgrasses (Davies et al. 2012). Compared to other species, HERB was parameterized with the shortest longevity (20 years) and the lowest shade and fire tolerance. This parameterization is in accordance with other LANDIS-II applications that also simulated a general grass species (e.g., Syphard et al. 2011).

Maximum ANPPs for each species at each land type were estimated for different climate scenarios using an ecosystem process model, PnET-II (Aber et al. 1995). PnET-II predicts how changes in climate (monthly mean of temperature, precipitation, and photosynthetically active shortwave radiation) affect ANPP of tree species. The model is based on a fundamental linear relationship between maximum net photosynthetic rate and leaf foliar nitrogen concentration (Reich et al. 1990). Other important species-specific canopy and photosynthesis parameters affecting ANPP in the model include leaf mass area, leaf retention year, and optimal photosynthetic temperature (Table 2). These parameters were obtained from the literature (e.g., Schlesinger et al. 1989; Wright et al. 2004) and have been used to simulate productivity of these species in similar LANDIS-II modeling applications, as initially developed by Xu et al. (2007).
SEPs, which were species- and land type-specific, were computed as the product of a growing-degreeday (GDD, with $5{ }^{\circ} \mathrm{C}$ being the base temperature) multiplier and a CWD multiplier, following the calculation of the reproduction reduction rate in the forest gap model LINKAGES (Post and Pastor 1996). However, unlike the symmetrical parabolic functions used in the LINKAGES model to compute GDD multipliers, we used asymmetrically parabolic functions between the minimum, median, and maximum degree-days tolerated by each species. The asymmetrical parabolic function assumes optimal temperaturerelated conditions for establishment at the median GDD value observed within the species distribution, and the multiplier is a parabolic function of GDD at both the left and right side of median GDD. The asymmetrical parabolic functions better represented the skewness of GDD distribution apparent in the Climate-Vegetation Atlas of North America (http:// pubs.usgs.gov/pp/p1650-b/datatables/index.html), where median GDD is typically closer to minimum GDD (Fig. 2a). Minimum and median GDD values were derived from species distribution records across the GDD gradient, while maximum GDD values were obtained from the Climate-Vegetation Atlas of North America (Table 2). The CWD multiplier is a half parabolic curve with value 1 when CWD is at zero, and the value zero when CWD is at the maximum level tolerated by the species (Fig. 2b).

We evaluated the validity of our model parameterization by simulating a random landscape (where the coverage of each species was the same as the existing 
Table 2 Key species canopy and photosynthetic parameters for PnET-II modeling, and key climatic parameters for computing SEPs

\begin{tabular}{lllllllll}
\hline Species & FNC & LMA & LRY & PsnT $_{\text {opt }}$ & GDD $_{\text {max }}$ & GDD $_{\text {md }}$ & GDD $_{\text {min }}$ & CWD $_{\text {max }}$ \\
\hline Aspen & 2.5 & 100 & 1 & 20 & 5,700 & 1,020 & 570 & 160 \\
Subalpine fir & 0.9 & 170 & 4 & 20 & 2,700 & 700 & 100 & 100 \\
Limber pine & 1.2 & 200 & 2.5 & 20 & 4,300 & 925 & 510 & 140 \\
Utah juniper & 0.8 & 150 & 2.25 & 22 & 4,700 & 2,000 & 600 & 350 \\
Mountain mahogany & 2.0 & 100 & 1 & 25 & 4,300 & 1,050 & 600 & 250 \\
Mountain shrubland & 1.8 & 100 & 1 & 25 & 3,500 & 1,050 & 600 & 190 \\
Sagebrush & 1.6 & 80 & 1 & 25 & 6,000 & 1,410 & 320 & 400 \\
\hline
\end{tabular}

FNC Foliar nitrogen content (\%), LMA leaf mass area $\left(\mathrm{g} \mathrm{m}^{-2}\right), L R Y$ leaf retention years (year), PsnT $T_{\text {opt }}$ optimum temperature for photosynthesis $\left({ }^{\circ} \mathrm{C}\right), G D D_{\max }, G D D_{m d}$, and $G D D_{\min }$ maximum, median, and minimum growing-degree-days $\left({ }^{\circ} \mathrm{C}\right.$, defined as the number of temperature degrees above a certain threshold base temperature, here is $5{ }^{\circ} \mathrm{C}$ ) tolerated by each species, $C W D_{\text {max }}$ maximum climatic water deficit $(\mathrm{mm})$ tolerated
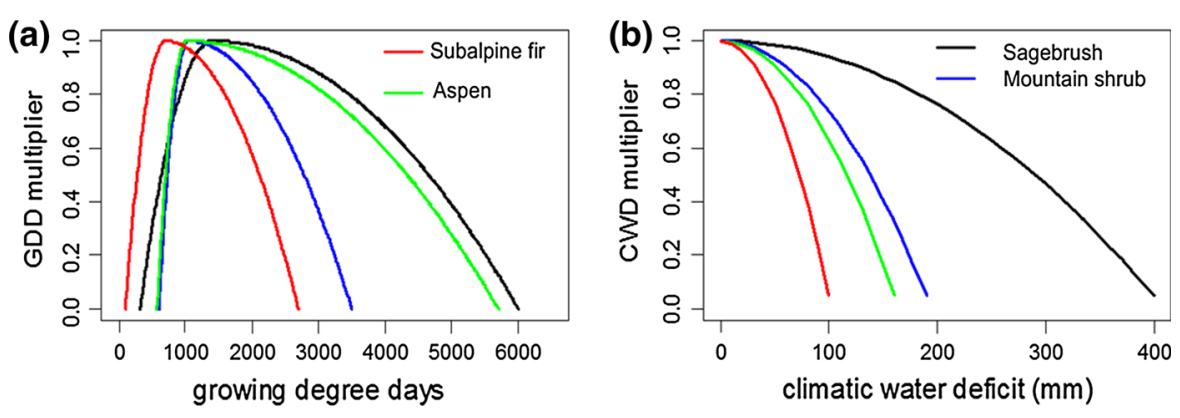

Fig. 2 a Growing degree days (GDD) multiplier, a reduction factor of plant species establishment probability used in LANDIS-II modeling, and b climate water deficit multiplier curves for aspen, subalpine fir, sagebrush, and mountain shrub functional type

vegetation map but the locations of those species were randomly assigned) for 1,000 years, and then comparing the simulation results to the existing vegetation map. Not only did the simulated area covered by major species (aspen, subalpine fir, and sagebrush) stabilize within $10 \%$ of the current coverage for each, but spatial locations of major species were generally in good agreement with the existing vegetation map (Cohen's Kappa coefficient $=0.73$, Appendix S5). In addition, species distributions along elevation gradients were generally similar to those computed from the existing vegetation map ( $t$ test of species coverage computed at each 100-m elevation bin was insignificant with $\mathrm{p}$ value $>0.1$, Appendix S6).

\section{Simulation design}

To assess the effects of climate warming and fire disturbance on vegetation distribution, we simulated a factorial experiment with two independent variables that each had three levels: climate (current, A2, and B1 carbon emission scenarios) and fire disturbance (contemporary fire frequency, doubled fire frequency, and fire exclusion). Each treatment was simulated with five replicates because of low variability of the landscapelevel outputs among replicates. The simulations were conducted at 10-year time steps over 150 years to model dynamics for at least 1 generation of aspen.

Current climate for our study area was obtained from PRISM data, while future climate data (to year 2099) were based on the projections of the NCAR CCSM (National Center for Atmospheric Research Community Climate System Model) under the A2 and B1 carbon emission scenarios. NCAR CCSM is a coupled climate model that simultaneously simulates the earth's atmosphere, ocean, land surface, and seaice (http://www.cesm.ucar.edu/). This model predicts a drier future compared to others (e.g., UK Hadley and 
Canada CCCma climate models). The A2 scenario represents high $\mathrm{CO}_{2}$ concentration $(\sim 850 \mathrm{ppm}$ at year 2099) due to high population size and slow technological adaptations, while the $\mathrm{B} 1$ scenario represents a less extreme $\mathrm{CO}_{2}$ increase ( $\sim 550 \mathrm{ppm}$ at year 2099) due to global integration of climate adaptations and introduction of resource-efficient technologies (IPCC 2007). Future climate data, with an original spatial resolution of $1 / 2^{\circ}$ on a latitude-longitude grid, were rescaled to $800 \mathrm{~m}$ spatial resolution using the PRISM data and a bias correction delta downscale approach (Maurer 2007). Downscaled, future climate data were averaged for each land type, and these values were provided as inputs in the PnET-II model to project future ANPPs. We also computed 30-year average monthly and yearly maximum, minimum, and mean temperature and precipitation for the years 2010 , 2040, 2070, and 2100. These data were used to compute future GDD and CWD input parameters for generating SEPs. We assumed constant climatic conditions for the years $2100-2149$ by repeating the parameters derived from the year 2070-2099 time period for all subsequent simulation periods. Mean annual temperature was predicted to increase by 4.8 and $1.8{ }^{\circ} \mathrm{C}$ by year 2100 under the $\mathrm{A} 2$ and $\mathrm{B} 1$ scenarios, while mean annual precipitation was predicted to decrease $10 \mathrm{~mm}$ and $8 \mathrm{~mm}$, respectively.

We did not consider the potential effects of climate warming on changing fire regime in this study. Rather, we superimposed three fire disturbance regime scenarios independently within each of the three climate scenarios: contemporary fire regime, complete fire exclusion (fire disturbance extension disabled), and a more frequent fire regime. For the frequent fire scenario, we doubled the input fire ignition density at each FRU so that the simulated fire rotation period would be half of each contemporary FRP (i.e., 30, 60, 120 , and 250 years). These decreased fire intervals are consistent with, or even conservative compared to, recent modeled predictions of fire activity in the western U.S. due to changes in climate, increases in development, and influence of non-native, fire-prone species (Littell et al. 2009; Abatzoglou and Kolden 2011; Westerling et al. 2011; Hawbaker et al. 2013).

\section{Data analysis}

We transformed the simulated measures of live biomass for species at 10 -yr time steps into vegetation types and created vegetation cover maps for further analysis. Vegetation types included (1) aspen forest, (2) subalpine fir forest (dominated mainly by subalpine fir and occasionally by limber pine or whitebark pine), (3) semi-arid woodlands (aggregate of mountain mahogany and Utah Juniper woodland), (4) mesic mountain shrubland (e.g., mountain snowberry), and (5) semi-arid shrub-grass (i.e., sagebrush-herbaceous mix). Sagebrush and the pseudo species HERB were combined to form the semi-arid generic shrub-grass type in order to maintain consistency with the USFS vegetation classification map that provided initial conditions for model simulations. To describe changes in vegetation composition, we computed the percentage of the entire landscape study area occupied by a specific vegetation type at regular time intervals across the 150-year simulation period.

To evaluate how simulated aspen distribution varied across topoclimatic gradients in response to alternative climate-fire scenarios, we computed aspen coverage at each combination of 12 elevation bands and 20 aspect bands (i.e., 240 topoclimatic bins) at simulation year 2149 under the 3 climate $\times 3$ fire scenarios. Aspect was first converted relative to southwest orientation $\quad$ (SWNESS $=\cos [$ (aspect $225) / 360 * \pi$ ]; Franklin et al. 2000) with a range of -1 (NE exposure) to 1 (SW exposure) to better distinguish mesic (low values) and xeric (high values) exposures, respectively. The elevation band width was $100 \mathrm{~m}$ and the aspect band width was 0.1 SWNESS. This resulted in aspen coverage values calculated for each of the 240 topoclimatic bins and for each of the 9 climate-fire scenarios, which were then plotted in twodimensional space that represents the elevation and SWNESS gradients.

We used linear regression to specifically quantify the potential influence of fire regime on aspen distribution under each climate scenario. For each of the three climate scenarios, the dependent variable was the simulated aspen coverage at year 2149 for each of the 240 individual topoclimatic bins, and the independent variable was the fire regime scenario (i.e., resulting in 720 individual regression models). The contemporary fire $(\mathrm{CF})$ regime scenario served as the baseline (i.e., the dummy variable); hence, the coefficients associated with the frequent fire (FF) and fire exclusion (NF) regimes in each regression model indicate the effect size induced by FF and NF regimes, respectively. For significant effects ( $p$ value $<0.01$ ), 
the corresponding FF and NF regime coefficients (i.e., the differences in simulated change of aspen coverage from the $\mathrm{CF}$ regime to the altered fire regimes) were plotted for each topoclimatic bin under each climate scenarios. We limited our comparative analyses to different fire regime effects within each climate scenario in order to estimate how alternative fire regimes are likely to modulate the unique climate response of aspen distribution across topoclimatic gradients.

\section{Results}

Species establishment probabilities

Species establishment probabilities (SEPs) varied greatly among functional vegetation types, elevation bands, and climate scenarios (Fig. 3). The SEP for aspen under current climate condition was relatively low $(<0.5)$ at low elevations, increased to a peak value of 0.75 at the mid-elevation band of $2,400 \mathrm{~m}$, and decreased to almost zero at the high elevation bands.
Under the future (year 2070-2099) climate warming scenarios, predicted aspen SEPs were greatly reduced for all elevation bands below 2,800 m, but were greater than under current climate for the highest elevation band. In contrast, SEPs of subalpine fir were reduced across the entire elevation gradient. The establishment probabilities of the mesic mountain shrubland functional type exhibited similar patterns in response to elevation and climate warming scenarios as aspen. Simulated SEPs of sagebrush under future climate scenarios were substantially reduced at low elevations but increased greatly at middle and upper elevations.

\section{Landscape composition dynamics}

Simulated coverage of aspen forest increased from $8.4 \%$ of total landscape to $10.4 \%$ over the entire 150 -year period under the current climate $\times$ contemporary fire regime $(\mathrm{CCCF})$ scenario and to $9.1 \%$ under the current climate $\times$ frequent fire regime $(\mathrm{CCFF})$ scenario (Table 3), but exhibited a conspicuous decreasing trend under the fire exclusion (CCNF) scenario (Fig. 4a). Simulated aspen coverage was
Fig. 3 Species establishment probabilities (SEPs) across elevation bands under current climate (CC), NCAR CCSM A2 emissions scenario, and NCAR CCSM B1 emissions scenario at year 2100 for quaking aspen, subalpine fir, mountain shrubland, and sagebrush. SEPs means are weighted by the aerial extent of each land type in an elevation band
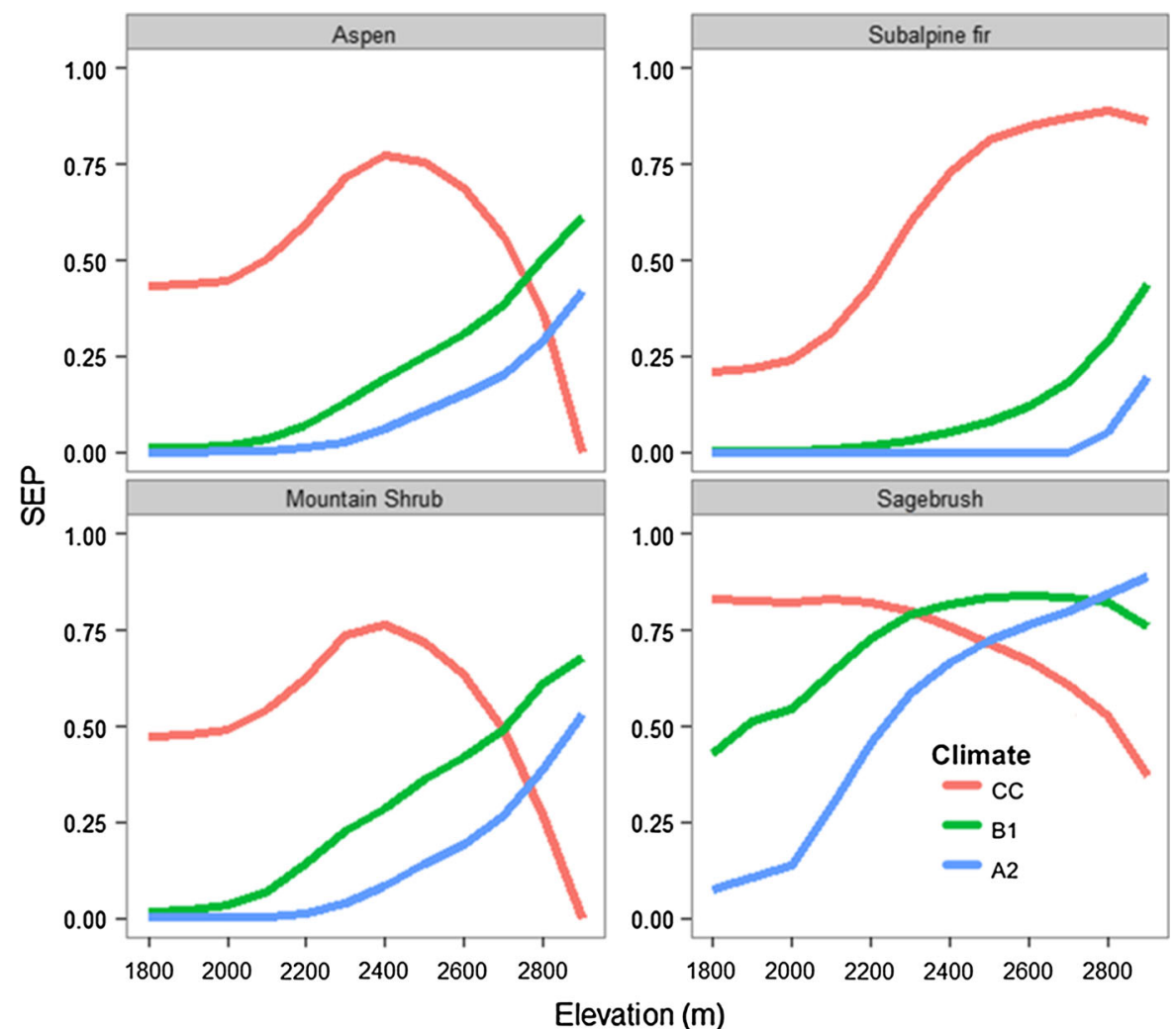
Table 3 Landscape-level mean coverage (\% of total area) for major vegetation types and its corresponding sample standard deviation (denoted in parenthesis) at the initial year and after

\begin{tabular}{|c|c|c|c|c|c|}
\hline $\begin{array}{l}\text { Vegetation } \\
\text { type }\end{array}$ & $\begin{array}{l}\text { Aspen } \\
\text { forest }\end{array}$ & $\begin{array}{l}\text { Subalpine } \\
\text { fir forest }\end{array}$ & $\begin{array}{l}\text { Mesic mountain } \\
\text { shrubland }\end{array}$ & $\begin{array}{l}\text { Semi-arid } \\
\text { shrub-grass }\end{array}$ & $\begin{array}{l}\text { Semi-arid } \\
\text { woodland }\end{array}$ \\
\hline Initial year & 8.4 & 7.5 & 12.7 & 67.1 & 4.3 \\
\hline \multicolumn{6}{|c|}{ After 150 simulation years } \\
\hline $\mathrm{CCCF}$ & $10.4(0.3)$ & $9.1(0.2)$ & $9.2(0.2)$ & $65.1(1.4)$ & $6.2(0.8)$ \\
\hline $\mathrm{CCFF}$ & $9.1(0.8)$ & $6.9(0.5)$ & $6.1(0.6)$ & $74.9(2.0)$ & $3.0(0.9)$ \\
\hline $\mathrm{CCNF}$ & $4.5(*)$ & $14.2(* *)$ & $4.6(* *)$ & $57.4(0.1)$ & $19.3(*)$ \\
\hline $\mathrm{B} 1 \mathrm{CF}$ & $5.4(0.3)$ & $5.7(0.5)$ & $3.2(* *)$ & $80.5(1.7)$ & $5.2(1.1)$ \\
\hline $\mathrm{B} 1 \mathrm{FF}$ & $4.7(0.3)$ & $4.3(0.1)$ & $2.4(0.1)$ & $86.3(0.8)$ & $2.3(0.5)$ \\
\hline $\mathrm{B} 1 \mathrm{NF}$ & $2.3(*)$ & $10.4(* *)$ & $1.5(* *)$ & $70.1(*)$ & $15.7(*)$ \\
\hline $\mathrm{A} 2 \mathrm{CF}$ & $4.3(0.1)$ & $4.0(0.6)$ & $1.9(*)$ & $85.6(0.5)$ & $4.2(0.3)$ \\
\hline $\mathrm{A} 2 \mathrm{FF}$ & $3.6(0.3)$ & $2.8(0.4)$ & $1.5(0.2)$ & $90.0(0.7)$ & $2.2(0.3)$ \\
\hline $\mathrm{A} 2 \mathrm{NF}$ & $1.8(* *)$ & $7.6(* *)$ & $1.1(* *)$ & $76.0(* *)$ & $13.6(* *)$ \\
\hline
\end{tabular}

* Denotes $<0.1$ and $>0.05$

$* *$ Denotes $<0.05$

reduced under the $\mathrm{B} 1$ and $\mathrm{A} 2$ climate scenarios for all fire regime scenarios (Fig. 4a). Under any given climate condition, simulations with fire always lead to a higher mean aspen coverage than the scenario without fire, but the simulated mean aspen coverage under FF scenario was smaller than CF scenario. The simulated mean aspen coverage at year 2149 decreased with an increasing warmer climate and over a fire regime gradient from contemporary, frequent, to no fire (Table 3).

The coverage of subalpine fir, the major competitor species of aspen at upper elevations, was predicted to increase greatly over the 150 simulation years (from $7.5 \%$ at year 2000 to $14.2 \%$ at year 2149) under the fire exclusion scenario and current climate conditions (Fig. 4b). This increasing trend was reduced in response to warming climates, with simulated coverage at year 2149 being 10.4 and $7.6 \%$ under B1 and A2 scenarios respectively (Table 3). For all climate scenarios, increasing fire frequency was predicted to reduce coverage of subalpine fir (Fig. 4b).

Semi-arid woodland, a minor vegetation type of the current landscape, was predicted to increase greatly under fire exclusion scenarios and to shrink its distribution under FF scenarios (Fig. 4c). Under any given fire scenario, its coverage under warming climate conditions was smaller than under current climate condition. Its simulated coverage at year 2149 decreased
150 simulation years for combinations of 3 climate scenarios (CC: current climate, B1, and A2) and 3 fire scenarios (CF: contemporary fire, FF: frequent fire, and NF: fire exclusion)

with an increasing warmer climate and over a fire regime gradient from no fire, contemporary, to frequent (Table 3).

Our simulations predicted that the coverage of mesic mountain shrubland, which had similar SEPs across the elevation gradient as aspen (Fig. 3), would also decrease in response to climate warming. Fire was predicted to help this vegetation type to persist on the landscape, while fire exclusion would eventually lead to a large reduction of its coverage. The differences in simulated coverage between no fire (NF) and fire scenarios $(\mathrm{CF}, \mathrm{FF})$, however, were relatively minor at the end of simulation (Fig. 4d).

Semi-arid shrub-grassland, the predominant vegetation on the landscape, was predicted to gain further dominance in response to climate warming. Increased fire frequency would further increase its coverage (Fig. 4e), though the respective contribution of sagebrush versus the herbaceous component is not differentiated here. Its simulated coverage at year 2149 decreased with an increasing warmer climate and over a fire regime gradient from no fire, contemporary, to frequent (Table 3). The ranking of the simulated coverage at year 2149 for this vegetation type, in decreasing order, was: $\mathrm{A} 2 \times \mathrm{FF}$ (frequent fire), B1 $\times \mathrm{FF}, \mathrm{A} 2 \times \mathrm{CF}$ (contemporary fire), $\mathrm{B} 1 \times \mathrm{CF}, \mathrm{A} 2 \times \mathrm{NF}$ (fire exclusion), $\mathrm{CC} \times \mathrm{FF}, \quad \mathrm{B} 1 \times \mathrm{NF}, \quad \mathrm{CC} \times \mathrm{CF}, \quad$ and $\mathrm{CC} \times \mathrm{NF}$ (Table 3). 
Fig. 4 Landscape-level coverage of a aspen, b subalpine fir, c semi-arid woodland, $\mathbf{d}$ mesic shrubland, and e semi-arid shrub-grass under three climate scenarios (CC: current climate, NCAR CCSM A2, NCAR CCSM B1) $\times$ three fire regime scenarios $(\mathrm{CF}$ :

contemporary fire scenario, FF: frequent fire regime, and NF: no fire) over 150 simulation years
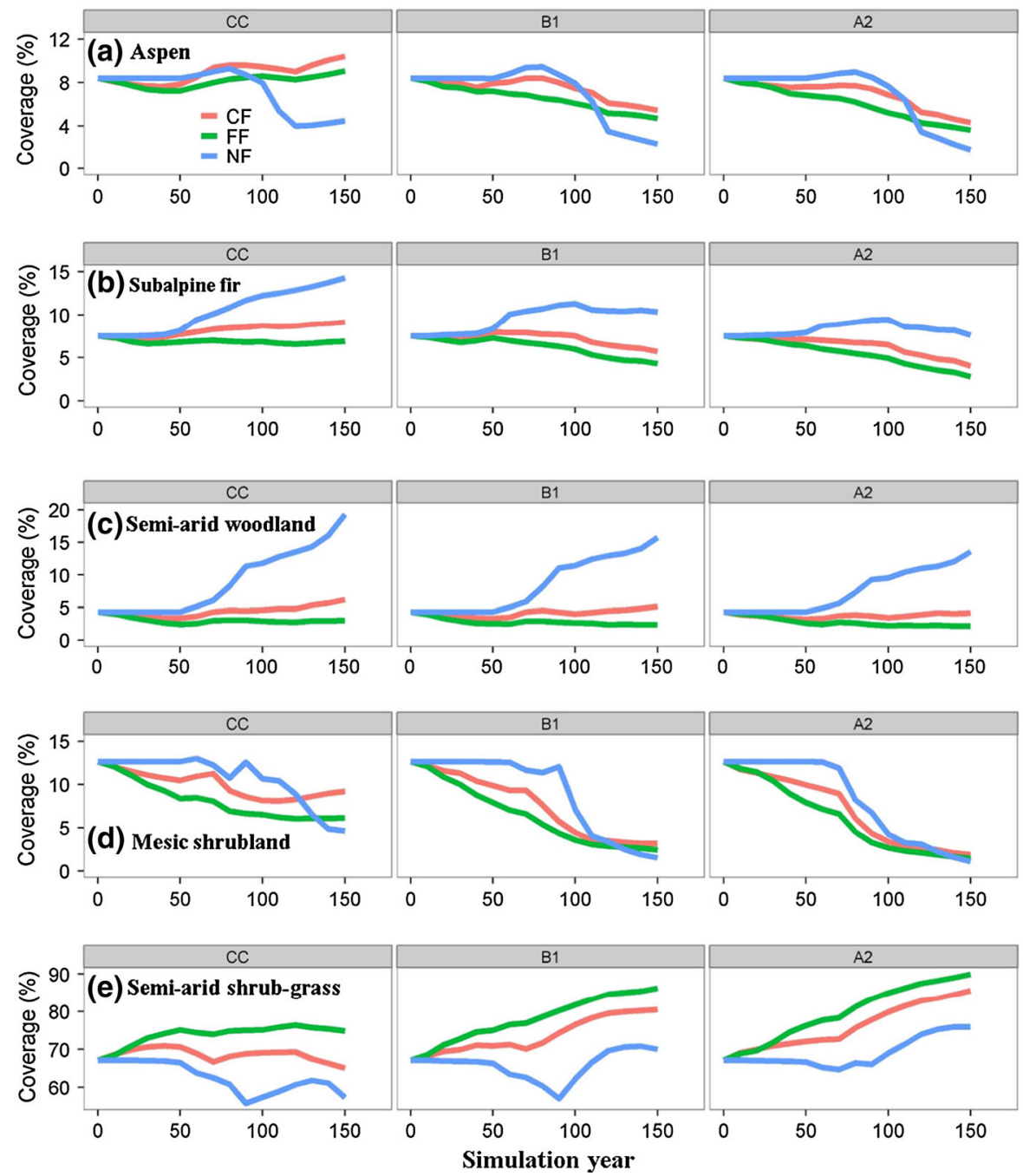

Spatial patterns of aspen distribution under climate change and fire scenarios

Different climate change scenarios resulted in noticeable differences in simulated distributional limits of aspen along topographic gradients defined by aspect and elevation (Fig. 5). Comparing to the contemporary distribution (Appendix S7), simulated future aspen distributions generally had greater coverage at the higher elevations and less coverage at lower elevations. As represented by $100 \mathrm{~m}$ elevation bands, lower elevation limits (trailing edges) for the simulated future aspen distribution shifted upward from $1,900 \mathrm{~m}$ for current climate $(\mathrm{CC}) \times$ contemporary fire (CF) scenario (Fig. 5a), to 2,000 $\mathrm{m}$ for the B1x CF and $\mathrm{A} 2 \times \mathrm{CF}$ scenarios (Fig. $5 \mathrm{~d}, \mathrm{~g}$ ), and to $2,100 \mathrm{~m}$ for the $\mathrm{A} 2 \times$ fire exclusion (NF) scenario (Fig. 5i). Upper elevation limits (leading edges) of simulated aspen distribution increased from 2,800 $\mathrm{m}$ under the $\mathrm{CC} \times \mathrm{FF}$ (frequent fire) (Fig. 5b) to 2,900 m under the A2 $\times$ FF scenario (Fig. 5h). Aspen largely contracted to more mesic aspects at all elevations under climate change, irrespective of fire regime (Fig. 5).

Although aspen distribution was reduced under climate change scenarios, spatial patterns of aspen coverage showed persistence in many locations where aspen is currently most abundant (Fig. 5 vs. Appendix S7). This pattern was consistent across all climate $\times$ fire scenarios even though the overall coverage at landscape scale had great differences. For 
Fig. 5 Simulated quaking aspen coverage $(\%)$ at each combination of $100-\mathrm{m}$ elevational band and 0.1-interval SWNESS (with -1.0 indicating NE aspect and 1.0 indicating SW aspect) band at year 2149 for the combinations of 3 climate scenarios: current climate (CC), NCAR CCSM B1, and NCAR CCSM A2 carbon emission scenarios and 3 fire regime scenarios: current fire regime (CF), frequent fire regime (FF) and no fire (NF). Only aspen coverage values $>1 \%$ are shown (a) $\mathrm{CCCF}$

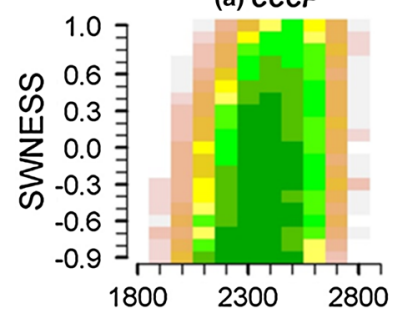

(d) $\mathrm{B1CF}$

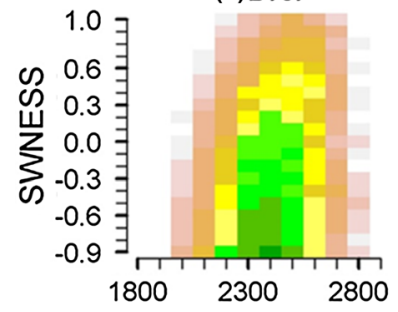

(g) $A 2 C F$

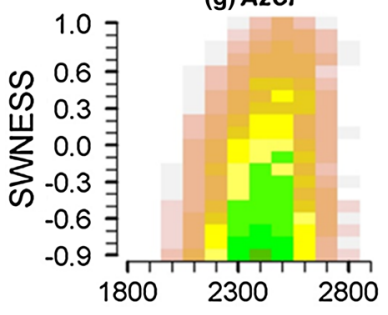

(b) CCFF

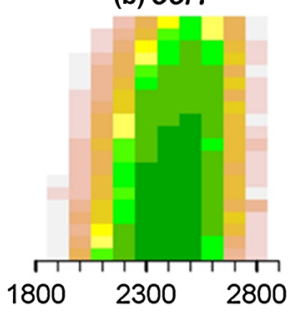

(e) B1FF

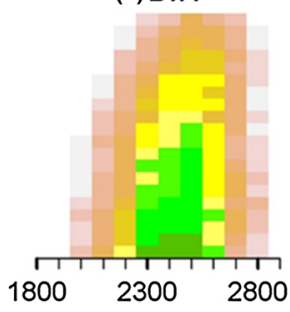

(h) A2FF

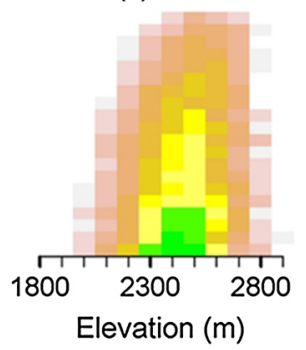

(c) CCNF

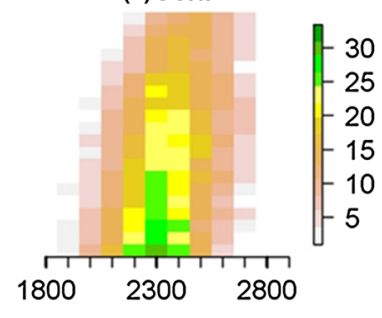

(f) $B 1 N F$

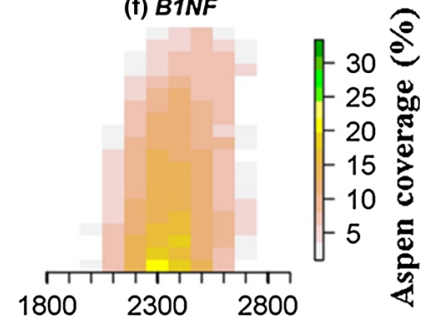

(i) A2NF

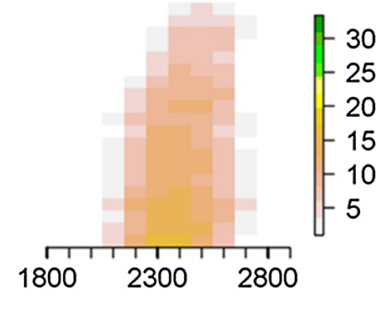

example, under the $\mathrm{CF}$ regime, simulated aspen coverage at year 2149 was predicted to decrease sharply under the B1 and A2 scenario relative to the CC scenario (Fig. 4). However, areas with highest aspen coverage occupied similar positions along the topoclimatic gradient across the CCCF, B1CF, and A2CF scenarios (Fig. 5, left three panels), mainly distributed in the middle elevation bands $(2,300 \mathrm{~m}$ to $2,500 \mathrm{~m}$ ) and more mesic aspects (SWNESS $<-0.5$ ).

The spatial pattern of aspen distribution under a FF scenario (Fig. 5, middle three panels) was quite similar to that of the CF scenario (Fig. 5, left three panels). The optimal elevation bands with highest aspen coverage was similar, but the distributional limits of aspen advanced to higher elevations (Fig. 5g vs. h). Conversely, simulated distributional limits of aspen under a fire exclusion (NF) scenario were greatly reduced (Fig. 5, right three panels), although aspen still persisted in abundance on more northeasterly aspects (SWNESS $<-0.5$ ) at elevations from 2,300 to $2,500 \mathrm{~m}$, depending on climate scenario.
Influences of altered fire regimes on aspen distribution along topoclimatic gradients

Influences of altered fire regimes (FF and NF) on aspen distribution, measured by the changes of aspen coverage from that simulated under the $\mathrm{CF}$ scenario, showed varied direction and magnitude along different elevation and aspect gradients and under different climate scenarios (Fig. 6). Fire influence was the largest under the current climate scenario and the lowest under the A2 scenario. Simulated aspen coverage under a $\mathrm{FF}$ regime was greater than under the $\mathrm{CF}$ regime at elevations $>2,500 \mathrm{~m}$ but smaller at elevations from $2,000 \mathrm{~m}$ to $2,300 \mathrm{~m}$. This pattern was most pronounced for the CC scenario, less apparent for the B1 scenario, and difficult to observe for the A2 scenario due to lack of statistical significance resulting from a low sample size of cells remaining with aspen coverage. Fire exclusion (NF) reduced aspen coverage across all elevation and aspect gradients where aspen was predicted to be present under the $\mathrm{CF}$ scenario. The biophysical settings showing the strongest negative 


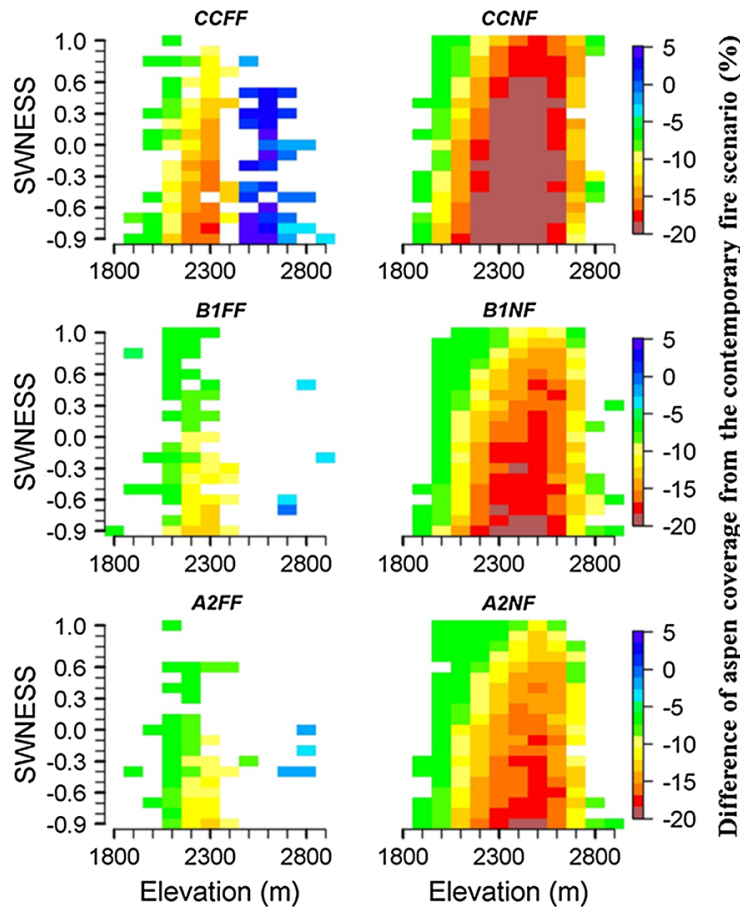

Fig. 6 Effect size of frequent fire (FF) and no fire (NF) scenarios, measured by the absolute difference of simulated aspen coverage $(\%)$ between the altered fire regime scenarios and the contemporary fire (CF) scenario at year 2149 under 3 climate scenarios: current climate (CC), NCAR CCSM B1, and NCAR CCSM A2 carbon emission scenarios. Results are shown by combinations of 100-m elevational bands and 0.1-interval of SWNESS (Southwestness with -1.0 indicating NE aspect and 1.0 indicating SW aspect). Only significant effects ( $\mathrm{p}$ value $\leq 0.01$ ) are shown

influences response to fire exclusion were elevation band 2,300-2,400 $\mathrm{m}$ and SWNESS $<0$, where aspen coverage was the highest under the corresponding $\mathrm{CF}$ scenario.

\section{Discussion}

Climate change effects on landscape dynamics and aspen distribution

Our simulation experiment suggested that under the future climate warming scenarios considered, aspen and coniferous forest would be greatly reduced in areal extent as much of the semi-arid landscape transitions to shrub and ruderal communities. This is not surprising given that the projected temperatures under the A2 scenario would result in a mean annual temperature at the highest elevation band in year 2100 that would be similar to that of the lowest elevation band under current climate conditions, where semi-arid shrubgrassland currently dominates $96 \%$ of land area (Fig. 1). Longer growing seasons could favor many upland tree species. However, the increased evapotranspiration associated with warming temperatures can lead to increased water stress, mortality and regeneration failure, and ultimately to distributional shifts of tree species away from their water-limited range limits (Romme and Turner 1991). Recent empirical studies have demonstrated the importance of CWD in determining species distribution and its response to climate change (Lutz et al. 2010; Crimmins et al. 2011). Anderegg et al. (2013) showed that widespread aspen die-off that occurred across Colorado, USA in 2002 could be attributed to growing season CWD more than precipitation deficit. Although future precipitation levels in our study area were predicted by the NCAR model to be similar to the modern period, a dramatic increase in CWD was ultimately responsible for the simulated compositional shift of drought-intolerant species such as aspen and fir to more drought-tolerant species.

Projections of shifts or overall declines in species distribution and abundance in response to climate change are a common outcome of climate change response models (e.g., Rehfeldt et al. 2009), but these often provide limited information about detailed nature of the response, as is needed to infer ecological mechanisms. In our study, the more informative results were those describing the distributional shifts for aspen and associated species. We found climate change produced only a modest increase in aspen distribution at upper elevation, a more substantial upward shift in the lower elevation range, and an overall contraction to the most mesic environments (e.g., Fig. 5d vs. Appendix S7), leading to an overall reduction of aspen range. The greater retraction of aspen distribution along trailing edges than advance along leading edges was in part due to the limited size of the area available on the leading edge, as there was a relatively small area of high-elevation habitat (Appendix S2). It may also be partly attributed to greater sensitivity of CWD to changes in temperature at warmer and drier sites at low elevations. This sensitivity results from the nonlinear relationship between temperature and vapor pressure deficit (Crimmins 
et al. 2011). The great increase of CWD at low elevations (Appendix S8) resulted in a large simulated reduction in aspen SEP along its trailing edges (Fig. 3), leading to high probability of seedling recruitment failure in those locations. Conversely, the simulated increase of aspen SEP along the leading edge was relatively modest. Moreover, many high elevation areas are currently dominated by subalpine fir forest, which can reduce light availability and alter soil chemistry in a way that places greater physiological and growth constraints on aspen recruitment (Calder et al. 2011).

Our use of a spatially-explicit simulation model helped to identify environmental settings that can serve as climate change refugia (Keppel et al. 2012; Rogers et al. 2013) for aspen, where it has the greatest potential to persist regardless of climate scenario or fire regime. Unlike previous topoclimatic methods for locating potential refugia that are mainly based on microtopography and climate stability (Dobrowski 2011; Ashcroft et al. 2012; Bell et al. 2014), the simulation modeling method can account for additional important constraints such as disturbance dynamics, biological legacy effects, and interspecific interactions. We observed aspen persistence on the most mesic aspects in the approximate center of its current elevation range. Such locations may be most suitable as refugia due to a combination of factors: (1) these areas experience less water stress given warming temperatures than warmer (e.g., southwest-facing aspects) and drier sites (e.g., low elevations) (Appendix S8) (2) they are too low in elevation to be suitable for aspen's more shade-tolerant competitor - subalpine fir, and they are high enough to escape strong competition from xeric herb and shrub species; and (3) they are often locations of persistent snow ("snow pockets") where aspen is well adapted to persist in soils with rich organic matter and high water holding capacity (Strand et al. 2009a).

Fire effects on climate change response of aspen

Aspen has been widely regarded as a fire-adapted species (Kaye et al. 2005; Clair et al. 2010; Smith et al. 2011). However, new studies have found more diverse responses of aspen to fire, depending on various aspen functional types (e.g., seral aspen and stable aspen) and topoclimatic conditions (Shinneman et al. 2013). Our modeling resulted in more than $50 \%$ of the current aspen coverage persisting for 150 years without fire under the current climate (CCNF) scenario (Table 3). This suggests that a majority of aspen on the landscape could be considered fire-independent, likely due to a lack of late-successional conifer competitors. For instance, spatial patterns of stable aspen coverage on south-facing slopes at high elevations simulated under the CCNF scenario (Fig. 5c) corroborate observational studies in similar semi-arid mountain landscapes (e.g., Strand et al. 2009b), in which aspen stands were found to be less affected by conifer encroachment in topographic positions that are generally either too dry or too cold for most conifers.

Although not all aspen stands depend on fire, fire can promote aspen coverage by causing extensive mortality of competing species, stimulating aspen resprouting, and creating open space for its colonization (Shinneman et al. 2013). This is demonstrated in our modeling as aspen coverage simulated under fire scenarios was much greater than that under fire exclusion scenarios (Fig. 4). However, landscapelevel aspen coverage simulated under the CF scenario was slightly larger than that simulated with the FF scenario (Table 3). Although doubling fire frequency across all elevations favored aspen over subalpine fir at the higher elevations in our simulations, it favored shrub and herbaceous species at the trailing edges of aspen distribution (Fig. 6), where mean fire return intervals varied from 30 to 60 years under the FF scenario. Such simulated detrimental effects of FF at lower elevations were mainly because (1) resprouting failure could occasionally occur in our simulations due to the modeled ungulate herbivory effects; (2) seedling establishment probability was low at those locations where CWD was high; and (3) the recruitment of suckers or seedlings into aspen stands was limited by strong inter-species competition and aspen's low growth/competitive potential (i.e., low maxANPP) at those marginal land types. Our simulation results suggest that seral aspen stands are supported by critical windows of fire frequency and modulated by life history traits of vegetative competitors (i.e., varying impacts of fire frequency depending on the competition from subalpine fir or shrub/herb).

Forest landscape succession and disturbance modeling

We considered thermal limitation and water availability to be the most important environmental controls of 
vegetation distribution. The lower-elevation distributional limit of trees in water-limited landscapes is generally determined by climate influences relating to plant water balance and soil drought (Daubenmire 1943; Romme and Turner 1991). Moreover, empirical studies have demonstrated that seedling establishment is critical for tree species to migrate along latitudinal (Zhu et al. 2012) or altitudinal gradients (Smith et al. 2003) in response to climate variability. Therefore, incorporating the terrain-driven influence of climatic water balance on tree species recruitment in forest landscape modeling is a critical consideration for simulating vegetation response to climate change in arid and semi-arid mountain landscapes. The importance of incorporating the influence of fire on species distributions under climate change was also apparent in our model simulations, with different fire regimes showing the potential to facilitate or impede aspen's ability to track shifting, suitable, topoclimatic habitats. However, our modeling did not directly consider drought mortality of mature trees (e.g., Gustafson and Sturtevant 2012) or other mortality events (e.g., insect outbreaks; Weed et al. 2013) that will likely increase with warming climate. Studies have shown that the invasive annual grasses such as cheatgrass are gaining dominance on the areas previously dominated by native bunch grasses and shrubs, leading to a shorter fire return interval on the Great Basin rangelands and changes in post-fire vegetation community assembly process (Mack and D'Antonio 1998; Chambers et al. 2007). Such effects are important in driving the dynamics of Intermountain landscapes and fire, but not adequately incorporated in our simulation. In this study, we didn't differentiate sub species within shrub and herbaceous communities. For example, sagebrush in our study area can be either Wyoming big sagebrush or mountain big sagebrush, and their distribution and function are quite distinctive. Grouping them may be sufficient for examining the interactions between aspen forest and other plant communities, but not enough to make inferences on the changes within communities of shrub and herb. Migration of species that are currently not in the local species pool may also play an important role in landscape response to climate and fire. Further research is needed to incorporate these mortality dynamics, multiple disturbances, species invasion, detailed shrub and herbaceous communities, and species migration into forest landscape modeling to better project future species distributions in semi-arid mountain landscapes.

To the best of our knowledge, this is the first study to combine CWD and fine-scale physiography in process-based modeling of forest landscape dynamics. Our modeling study highlights the importance of incorporating the influence of terrain on climatic water balance and ecohydrology in modeling the response of species distribution to climate change, which has been demonstrated in modeling shrublands of dry regions (Schlaepfer et al. 2012) but less so for mountain forests. Our simulations indicated that drought-intolerant foundation tree species such as quaking aspen could experience greatly reduced distributions in the more arid portions of their existing ranges due to water stress limitations under future climate warming scenarios. However, even at the most xeric portions of its range, aspen is likely to persist in certain environmental settings due to unique and often fine-scale combinations of resource availability, species interactions and disturbance regime. Our modeling approach allowed identification of these refugia. In addition, this approach helped quantify how the direction and magnitude of fire influences on aspen distribution vary across topoclimatic gradients and under various climate scenarios, as well as further our understanding of the role of environmental conditions, fire, and interspecific competition in shaping potential responses of species distributions to climate change.

Acknowledgments Funding was provided by the U.S. Geological Survey National Climate Change and Wildlife Science Center (NCCWSC). Any use of trade, product, or firm names is for descriptive purposes only and does not imply endorsement by the U.S.G.S. We thank Steve Garman and two anonymous reviewers for helpful reviews that helped us improve the manuscript.

\section{References}

Abatzoglou JT, Kolden CA (2011) Climate change in western US deserts: potential for increased wildfire and invasive annual grasses. Rangel Ecol Manag 64(5):471-478

Aber JD, Ollinger SV, Fédérer CA, Reich PB, Goulden ML, Kicklighter DW, Lathrop RG (1995) Predicting the effects of climate change on water yield and forest production in the northeastern United States. Clim Res 5(3):207-222

Allen CD, Macalady AK, Chenchouni H, Bachelet D, McDowell N, Bennetier M, Kitzberger T, Vennetier M, 
Kitzberger T, Breshears DB, Hogg EH, Gonzalez P, Fensham R, Zhang Z, Castro J, Demidova N, Lim LH, Allard G, Running SW, Semerci A, Cobb N (2010) A global overview of drought and heat-induced tree mortality reveals emerging climate change risks for forests. For Ecol Manag 259(4):660-684

Anderegg LD, Anderegg WR, Abatzoglou J, Hausladen AM, Berry JA (2013) Drought characteristics' role in widespread aspen forest mortality across Colorado, USA. Glob Change Biol 19:1526-1537

Araújo MB, Luoto M (2007) The importance of biotic interactions for modelling species distributions under climate change. Glob Ecol Biogeogr 16(6):743-753

Ashcroft MB, Gollan JR, Warton DI, Ramp D (2012) A novel approach to quantify and locate potential microrefugia using topoclimate, climate stability, and isolation from the matrix. Glob Change Biol 18(6):1866-1879

Baker WL (2009) Fire ecology in Rocky Mountain landscapes. Island Press, Washington, D.C.

Beck JL, Peek JM, Strand EK (2006) Estimates of elk summer range nutritional carrying capacity constrained by probabilities of habitat selection. J Wildl Manag 70(1):283-294

Beckage B, Osborne B, Gavin DG, Pucko C, Siccama T, Perkins $\mathrm{T}$ (2008) A rapid upward shift of a forest ecotone during 40 years of warming in the Green Mountains of Vermont. Proc Natl Acad Sci 105(11):4197-4202

Bell DM, Bradford JB, Lauenroth WK (2014) Mountain landscapes offer few opportunities for high-elevation tree species migration. Glob Change Biol 20:1441-1451

Bond WJ, Keeley JE (2005) Fire as a global 'herbivore': the ecology and evolution of flammable ecosystems. Trends Ecol Evol 20(7):387-394

Breshears DD, Cobb NS, Rich PM, Price KP, Allen CD, Balice RG, Romme WH, Kastens JH, Floyd ML, Belnap J, Anderson JJ, Myers OB, Meyer CW (2005) Regional vegetation die-off in response to global-change-type drought. Proc Natl Acad Sci 102(42):15144-15148

Breshears DD, Huxman TE, Adams HD, Zou CB, Davison JE (2008) Vegetation synchronously leans upslope as climate warms. Proc Natl Acad Sci 105(33):11591-11592

Calder WJ, Horn KJ, Clair SBS (2011) Conifer expansion reduces the competitive ability and herbivore defense of aspen by modifying light environment and soil chemistry. Tree Physiol 31(6):582-591

Chambers JC, Roundy BA, Blank RR, Meyer SE, Whittaker A (2007) What makes Great Basin sagebrush ecosystems invasible by Bromus tectorum? Ecol Monogr 77(1):117-145

Chen I-C, Hill JK, Ohlemüller R, Roy DB, Thomas CD (2011) Rapid range shifts of species associated with high levels of climate warming. Science 333(6045):1024-1026

Chong GW, Simonson SE, Stohlgren TJ, Kalkhan MA (2001) Biodiversity: aspen stands have the lead, but will nonnative species take over? USDA Forest Service Proceedings RMRS-P-18

Clair SBS, Guyon J, Donaldson J (2010) Quaking aspen's current and future status in western North America: the role of succession, climate, biotic agents and its clonal nature. Progress in Botany 71, Springer, pp 371-400

Crimmins SM, Dobrowski SZ, Greenberg JA, Abatzoglou JT, Mynsberge AR (2011) Changes in climatic water balance drive downhill shifts in plant species' optimum elevations. Science 331(6015):324-327

Daly C, Halbleib M, Smith JI, Gibson WP, Doggett MK, Taylor GH, Pasteris PP (2008) Physiographically sensitive mapping of climatological temperature and precipitation across the conterminous United States. Int J Climatol 28(15): 2031-2064

Daubenmire RF (1943) Vegetational zonation in the Rocky Mountains. Bot Rev 9(6):325-393

Davies GM, Bakker JD, Dettweiler-Robinson E, Dunwiddie PW, Hall SA, Downs J, Evans J (2012) Trajectories of change in sagebrush steppe vegetation communities in relation to multiple wildfires. Ecol Appl 22(5):1562-1577

Dobrowski SZ (2011) A climatic basis for microrefugia: the influence of terrain on climate. Glob Change Biol 17(2): $1022-1035$

Flannigan MD, Krawchuk MA, de Groot WJ, Wotton M, Gowman LM (2009) Implications of changing climate for global wildland fire. Int J Wildland Fire 18(5):483-507

Franklin J, McCullough P, Gray C (2000) Terrain variables used for predictive mapping of vegetation communities in Southern California. In: Wilson JP, Gallant JC (eds) Terrain analysis: principles and applications. Wiley, Hoboken

Gustafson EJ, Sturtevant BR (2012) Modeling Forest Mortality Caused by Drought Stress: Implications for Climate Change. Ecosystems:1-15

Gustafson EJ, Shvidenko AZ, Sturtevant BR, Scheller RM (2010) Predicting global change effects on forest biomass and composition in south-central Siberia. Ecol Appl 20(3):700-715

Gustafson EJ, Kubiske ME, Sturtevant BR, Miranda BR (2013) Scaling Aspen-FACE experimental results to century and landscape scales. Landscape Ecol 28(9):1785-1800

Hanna P, Kulakowski D (2012) The influences of climate on aspen dieback. For Ecol Manage 274:91-98

Hawbaker TJ, Radeloff VC, Stewart SI, Hammer RB, Keuler NS, Clayton MK (2013) Human and biophysical influences on fire occurrence in the United States. Ecol Appl 23(3): $565-582$

Hessl AE, Graumlich LJ (2002) Interactive effects of human activities, herbivory and fire on quaking aspen (Populus tremuloides) age structures in western Wyoming. J Biogeogr 29(7):889-902

Heyerdahl EK, Brubaker LB, Agee J (2001) Spatial controls of historical fire regimes: a multiscale example from the interior west, USA. Ecology 82(3):660-678

Hughes L (2000) Biological consequences of global warming: is the signal already apparent? Trends Ecol Evol 15(2):56-61

IPCC (2007) Climate Change 2007: The physical science basis. Summary for policymakers. Contribution of working group I to the fourth assessment report. The Intergovernmental Panel on Climate Change. http://www.ipcc.ch/SPM2feb 07.pdf

Iverson LR, McKenzie D (2013) Tree-species range shifts in a changing climate: detecting, modeling, assisting. Landscape Ecol 28(5):879-889

Karam SL, Weisberg PJ, Scheller RM, Johnson DW, Miller WW (2013) Development and evaluation of a nutrient cycling extension for the LANDIS-II landscape simulation model. Ecol Model 250:45-57 
Kashian DM, Romme WH, Regan CM (2007) Reconciling divergent interpretations of quaking aspen decline on the northern Colorado Front Range. Ecol Appl 17(5):12961311

Kay CE (1993) Aspen seedlings in recently burned areas of Grand Teton and Yellowstone National Parks. Northwest Sci 67(2):94-104

Kay CE (1997) Is aspen doomed? J Forest 95(5):4

Kaye MW, Binkley D, Stohlgren TJ (2005) Effects of conifers and elk browsing on quaking aspen forests in the central Rocky Mountains, USA. Ecol Appl 15(4):1284-1295

Keeley JE, Pausas JG, Rundel PW, Bond WJ, Bradstock RA (2011) Fire as an evolutionary pressure shaping plant traits. Trends Plant Sci 16(8):406-411

Kelly AE, Goulden ML (2008) Rapid shifts in plant distribution with recent climate change. Proc Natl Acad Sci 105(33): 11823-11826

Keppel G, Van Niel KP, Wardell-Johnson GW, Yates CJ, Byrne M, Mucina L, Schut AGT, Hopper SD, Franklin SE (2012) Refugia: identifying and understanding safe havens for biodiversity under climate change. Glob Ecol Biogeogr 21(4):393-404

Krawchuk MA, Moritz MA, Parisien MA, Van Dorn J, Hayhoe K (2009) Global pyrogeography: the current and future distribution of wildfire. PLoS One 4(4):e5102

Kulakowski D, Veblen TT, Kurzel BP (2006) Influences of infrequent fire, elevation and pre-fire vegetation on the persistence of quaking aspen (Populus tremuloides Michx.) in the Flat Tops area, Colorado, USA. J Biogeogr 33(8):13971413

Lenihan JM, Bachelet D, Neilson RP, Drapek R (2008) Response of vegetation distribution, ecosystem productivity, and fire to climate change scenarios for California. Clim Change 87:215-230

Lenoir J, Gegout JC, Marquet PA, De Ruffray P, Brisse H (2008) A significant upward shift in plant species optimum elevation during the 20th century. Science 320(5884): 1768-1771

Lenoir J, Gégout JC, Guisan A, Vittoz P, Wohlgemuth T, Zimmermann NE, Dullinger S, Pauli H, Willner W, Svenning JC (2010) Going against the flow: potential mechanisms for unexpected downslope range shifts in a warming climate. Ecography 33(2):295-303

Linares JC, Camarero JJ, Carreira JA (2009) Interacting effects of changes in climate and forest cover on mortality and growth of the southernmost European fir forests. Glob Ecol Biogeogr 18(4):485-497

Littell JS, McKenzie D, Peterson DL, Westerling AL (2009) Climate and wildfire area burned in western US ecoprovinces, 1916-2003. Ecol Appl 19(4):1003-1021

Littell JS, Oneil EE, McKenzie D, Hicke JA, Lutz JA, Norheim RA, Elsner MM (2010) Forest ecosystems, disturbance, and climatic change in Washington State, USA. Clim Change 102(1-2):129-158

Littell JS, Peterson DL, Millar CI, O'Halloran KA (2012) US National Forests adapt to climate change through ScienceManagement partnerships. Clim Change 110(1-2):269-296

Loehle C, LeBlanc D (1996) Model-based assessments of climate change effects on forests: a critical review. Ecol Model 90(1):1-31
Long JN, Mock K (2012) Changing perspectives on regeneration ecology and genetic diversity in western quaking aspen: implications for silviculture. Can J For Res 42(12): 2011-2021

Lutz JA, van Wagtendonk JW, Franklin JF (2010) Climatic water deficit, tree species ranges, and climate change in Yosemite National Park. J Biogeogr 37(5):936-950

Mack MC, D'Antonio CM (1998) Impacts of biological invasions on disturbance regimes. Trends Ecol Evol 13(5):195198

Maurer EP (2007) Uncertainty in hydrologic impacts of climate change in the Sierra Nevada, California, under two emissions scenarios. Clim Change 82(3-4):309-325

McCool SF (2001) Quaking aspen and the human experience: dimensions, issues, and challenges. In: Sustaining aspen in western landscapes: Symposium Proceedings. RMRS-P18. Grand Junction, CO: US Dept. of Agriculture, Rocky Mountain Research Station, Forest Service Proceedings

McCune B, Keon D (2002) Equations for potential annual direct incident radiation and heat load. J Veg Sci 13(4):603-606

Mladenoff DJ, He HS (1999) Design, behavior and application of LANDIS, an object-oriented model of forest landscape disturbance and succession. Spatial modeling of forest landscape change: approaches and applications. Cambridge University Press, Cambridge, UK, pp 125-162

Morin X, Thuiller W (2009) Comparing niche-and processbased models to reduce prediction uncertainty in species range shifts under climate change. Ecology 90(5):13011313

Post WM, Pastor J (1996) LINKAGES - an individual-based forest ecosystem model. Clim Change 34(2):253-261

Rehfeldt GE, Crookston NL, Warwell MV, Evans JS (2006) Empirical analyses of plant-climate relationships for the western United States. Int J Plant Sci 167(6):1123-1150

Rehfeldt GE, Ferguson DE, Crookston NL (2009) Aspen, climate, and sudden decline in western USA. For Ecol Manage 258(11):2353-2364

Reich P, Ellsworth D, Kloeppel B, Fownes J, Gower S (1990) Vertical variation in canopy structure and $\mathrm{CO} 2$ exchange of oak-maple forests: influence of ozone, nitrogen, and other factors on simulated canopy carbon gain. Tree Physiology 7(1-2-3-4):329-345

Rogers PC, Eisenberg C, Clair S (2013) Resilience in Quaking Aspen: recent advances and future needs. For Ecol Manag 299:1-5

Romme WH, Turner MG (1991) Implications of global climate change for biogeographic patterns in the Greater Yellowstone Ecosystem. Conserv Biol 5(3):373-386

Romme WH, Turner MG, Tuskan GA, Reed RA (2005) Establishment, persistence, and growth of aspen (Populus tremuloides) seedlings in Yellowstone National Park. Ecology 86(2):404-418

Scheller RM, Mladenoff DJ (2004) A forest growth and biomass module for a landscape simulation model, LANDIS: design, validation, and application. Ecol Model 180(1):211-229

Scheller RM, Mladenoff DJ (2005) A spatially interactive simulation of climate change, harvesting, wind, and tree species migration and projected changes to forest composition and biomass in northern Wisconsin. USA. Glob Change Biol 11(2):307-321 
Scheller RM, Domingo JB, Sturtevant BR, Williams JS, Rudy A, Gustafson EJ, Mladenoff DJ (2007) Design, development, and application of LANDIS-II, a spatial landscape simulation model with flexible temporal and spatial resolution. Ecol Model 201(3):409-419

Schlaepfer DR, Lauenroth WK, Bradford JB (2012) Consequences of declining snow accumulation for water balance of mid-latitude dry regions. Glob Change Biol 18(6): 1988-1997

Schlesinger WH, DeLucia EH, Billings W (1989) Nutrient-use efficiency of woody plants on contrasting soils in the western Great Basin, Nevada. Ecology 70(1):105-113

Schoennagel T, Veblen TT, Romme WH (2004) The interaction of fire, fuels, and climate across Rocky Mountain forests. Bioscience 54(7):661-676

Schumacher S, Bugmann H (2006) The relative importance of climatic effects, wildfires and management for future forest landscape dynamics in the Swiss Alps. Glob Change Biol 12(8):1435-1450

Shinneman DJ, Palik BJ, Cornett MW (2012) Can landscapelevel ecological restoration influence fire risk? A spatiallyexplicit assessment of a northern temperate-southern boreal forest landscape. For Ecol Manage 274:126-135

Shinneman DJ, Baker WL, Rogers PC, Kulakowski D (2013) Fire regimes of quaking aspen in the Mountain West. For Ecol Manag 299(1):22-34

Smith WK, Germino MJ, Hancock TE, Johnson DM (2003) Another perspective on altitudinal limits of alpine timberlines. Tree Physiol 23(16):1101-1112

Smith EA, O'Loughlin D, Buck JR, St Clair SB (2011) The influences of conifer succession, physiographic conditions and herbivory on quaking aspen regeneration after fire. For Ecol Manag 262(3):325-330

Stephenson N (1998) Actual evapotranspiration and deficit: biologically meaningful correlates of vegetation distribution across spatial scales. J Biogeogr 25(5):855-870

Strand EK, Vierling LA, Bunting SC (2009a) A spatially explicit model to predict future landscape composition of aspen woodlands under various management scenarios. Ecol Model 220(2):175-191

Strand EK, Vierling LA, Bunting SC, Gessler PE (2009b) Quantifying successional rates in western aspen woodlands: current conditions, future predictions. For Ecol Manag 257(8):1705-1715

Sturtevant BR, Scheller RM, Miranda BR, Shinneman D, Syphard A (2009) Simulating dynamic and mixed-severity fire regimes: a process-based fire extension for LANDIS-II. Ecol Model 220(23):3380-3393
Syphard AD, Scheller RM, Ward BC, Spencer WD, Stritthold JR (2011) Simulating landscape-scale effects of fuels treatments in the Sierra Nevada, California, USA. Int J Wildland Fire 20(3):364-383

Temperli C, Bugmann HKM, Elkin C (2013) Cross-scale interactions among bark beetles, climate change and wind disturbances: a landscape modeling approach. Ecol Monogr 83:383-402

Ward BC, Mladenoff DJ, Scheller RM (2005) Simulating landscape-level effects of constraints to public forest regeneration harvests due to adjacent residential development in northern Wisconsin. For Sci 51(6):616-632

Weed AS, Ayres MP, Hicke J (2013) Consequences of climate change for biotic disturbances in North American forests. Ecol Monogr 83:441-470

Westerling AL, Turner MG, Smithwick EAH, Romme WH, Ryan MG (2011) Continued warming could transform Greater Yellowstone fire regimes by mid-21st century. Proc Natl Acad Sci 108(32):13165-13170

Worrall JJ, Marchetti SB, Egeland L, Mask RA, Eager T, Howell B (2010) Effects and etiology of sudden aspen decline in southwestern Colorado, USA. For Ecol Manag 260(5):638-648

Wright IJ, Reich PB, Westoby M, Ackerly DD, Baruch Z, Bongers F, Cavender-Bares J, Chapin T, Cornelissen JHC, Diemer M, Flexas J, Garnier E, Groom PK, Gulias J, Hikosaka K, Lamont BB, Lee T, Lee W, Lusk C, Midgley JL, Navas ML, Niinemets Ü, Oleksyn J, Osada N, Poorter H, Poot P, Prior L, Pyankov VI, Roumet C, Thomas SC, Tjoelker MG, Veneklaas EJ, Villar R (2004) The worldwide leaf economics spectrum. Nature 428(6985):821-827

Xu C, Gertner GZ, Scheller RM (2007) Potential effects of interaction between $\mathrm{CO} 2$ and temperature on forest landscape response to global warming. Glob Change Biol 13(7):1469-1483

Xu C, Gertner GZ, Scheller RM (2009) Uncertainties in the response of a forest landscape to global climatic change. Glob Change Biol 15(1):116-131

Yang J, He HS, Gustafson EJ (2004) A hierarchical fire frequency model to simulate temporal patterns of fire regimes in LANDIS. Ecol Model 180(1):119-133

Yang J, He HS, Shifley SR (2008) Spatial controls of occurrence and spread of wildfires in the Missouri Ozark Highlands. Ecol Appl 18(5):1212-1225

Zhu K, Woodall CW, Clark JS (2012) Failure to migrate: lack of tree range expansion in response to climate change. Glob Change Biol 18(3):1042-1052 